\title{
Az átpolitizálódás jelensége az UNESCO és a Világörökségi Bizottság tevékenységében
}

The Phenomenon of Politicisation in the Activities of UNESCO and the World Heritage Committee

Erdös Zeichner Anna

https://doi.org/10.47707/Kulugyi_Szemle.2021.2.6

Összefoglaló: Az ENSZ és szakosított szervezetei hosszú évek óta újra és újra az átpolitizálódás vádjával szembesülnek. Ez alól nem kivétel az Egyesült Nemzetek Nevelésügyi, Tudományos és Kulturális Szervezete - ismertebb ne vén: az UNESCO - sem. A tanulmányban megkísérelem meghatározni egyrészt az átpolitizálódás fogalmát, másrészt magának a jelenségnek a tartalmi jellemzőit. Ezt követően két korszak vonatkozó jellemzőinek a bemutatásával vázlatos történelmi áttekintést nyújtok az átpolitizálódásnak az UNESCO ban történt megjelenéséről és a szervezet és a Világörökségi Bizottság mun kájában való megjelenítéséről.

Kulcsszavak: ENSZ, UNESCO, átpolitizálódás, Palesztina, Koszovó, hidegháború

Abstract: The UN and its specialised agencies have been repeatedly confronted with accusations of politicisation for many years, and the United Nations Educational, Scientific and Cultural Organization - beller known as UNESCO - is no exception. In this study, I try to define the concept of politicisation and the content characteristics of the phenomenon itself. I then provide a brief historical overview of the emergence and the reflection of politicisation at UNESCO in the work of the organisation and the World Herilage Commiltee, presenting certain specific eras.

Keywords: UN, UNESCO, Politicisation, Palestine, Kosovo, Cold War 


\section{Bevezetés}

Az UNESCO és a Világörökségi Bizottság tevékenységének elemzé sekor - történelmi léptékben visszatekintve, de napjainkban is - újra és újra találkozhatunk az ún. politizálódás és átpolitizálódás szembeötlő jelenségével. A magyarban, de a nemzetközi színtéren döntően használt angol nyelvi változatában is mindkét szó - politicisation és overpoliticisation - művinek és nehézkesnek tûnik. A megjelenésük és a használatuk azonban nem csupán az UNESCO-hoz és annak alárendelt intézményeihez kapcsolódik, hanem érintheti az ENSZ többi szakosított intézményét is. Szükségesnek látszik ezért, hogy fogalmi meghatározást adjunk e kifejezéseknek, illetve elemezzük az általuk megjelenített tartalmat. Ugyanis bármilyen gyakorta használják is a különböző fórumokon - elsősorban - a politizálódás szót, bármennyire is gyakori maga a jelenség, a szakirodalmi feldolgozása mégis csupán eseti és erősen hiányos mind nemzetközi, mind hazai viszonylatban. 'Az ügy kényes, hiszen valamely szakosított ENSZ-intézménynél az alapokmánya által meghatározott szakmaiságból való kilépés, az annak kárára történő vagy azt háttérbe szorító, sőt elvető, illetve azzal ellentétes politizálódás és átpolitizálódás mögött általában és eredendően az érintett felek olyan véleményküiönbsége áll, amelyet kölcsönös megelégedéssel lezárni gyakorlatilag nem lehetett és - úgy tűnik - ma sem lehet. Megállapítható, hogy ma már abban sincs egyetértés, hogy adott esetben tényleg helytálló-e, egyáltalán a valóságnak megfelelő-e az e két szóban kifejezett értékelés.

A magyar „politizálódás” és „átpolitizálódás” kifejezés által megjelenített folyamatok, helyzetek, álláspontok leírásakor és minősítésekor nem teljes azonossággal használható a politicisation és az overpoliticisation szó. Az előbbi lényegét ugyanis az átpolitizálódás szó helyesebben adja vissza, a második angol kifejezéssel pedig csak

1 A hivatkozások a dolgozatban ezért döntően és többségében az UNESCO elektronikus irattárában megtalálható, angol vagy francia nyelvủ jegyzőkönyvi, tény megállapító, s sokkal kevésbé vagy egyáltalán nem elemzỏ jellegủ anyagokra vo natkoznak. Alapvető és átfogó forrásként lényegében egyetlen mú használható (Dutt, 1995). 


\section{Külïgyi Szemle}

nagyon ritkán lehet találkozni. A cikkben ezért a címben is szereplő magyar változatot fogom használni.

A következő fejezetben arra törekszem, hogy minél pontosabban meghatározzam az átpolitizálódás fogalmát, illetve magának a jelenségnek a tartalmi jellemzőit. Ezt követően egyes, meghatározott időszakok bemutatásával vázlatos történelmi áttekintést nyújtok az átpolitizálódás akkoriban érvényesült fỏ vonatkozásairól. E példaként kezelt történelmi időszakok a következők: a hidegháborús feszülltség kora, illetve a gyarmati rendszer megszűnésének évei. Az utolsó részben Palesztina és Koszovó esetén keresztül mutatom be az átpolitizálódás erőteljes megjelenését, megjelenítését az UNESCO és a Világörökségi Bizottság munkájában.

\section{Az átpolitizálódás fogalma és tartalma}

Az UNESCO-ban tapasztalható folyamatok, fejlemények, tendenciák értékelésekor is vissza kell nyúlnunk az ősforráshoz, a szervezet alap okmányához, mert ez esetben is az lehet minden viszonyítás alapja.

Az UNESCO-nak, az Egyesült Nemzetek Nevelésügyi, Tudományos és Kulturális Szervezetének alkotmánya (a továbbiakban: Alkotmány; Wolters Kluwer, 2009)² abból indul ki, hogy „a háborúk az emberek tudatában keletkeznek, az emberek tudatában kell a béke védelme érdekében munkálkodni. Az emberiség történelme folyamán az egymás kölcsönös meg nem értése volt a népek közötti gyanakvás és bizalmatlanság oka, miáltal ezen nézeteltérések igen gyakran vezettek háború kitöréséhez”. Így a második „nagy és borzalmas háború azáltal vált lehetővé, hogy az emberi méltóság, egyenlőség és kölcsönös tisztelet demokratikus eszményét megtagadták, s helyüike a tudatlanságot és elốtéletet kihasználva az emberek és fajok közötti egyenlőtlenség tanát akarták állítani”. Az Alkotmány hangsúlyozza, hogy

2 A hivatalos magyar szövegben az Általános Konferencia elnevezés szerepel, de a magyar diplomáciai gyakorlat és szakirodalom az UNESCO ezen irányító fórumát Közgyűlésnek nevezi. Ennek megfelelően járok el én is. Ezzel az elnevezéssel azonban kisebb, de lényegi pontatlanság is együtt járhat: a Közgyưlés dönt valamiről valamelyik ülésszakán, de helytelen például „a Közgyűlésen döntöttek valamiről" típusú szófordulat. 
az emberi méltóság megköveteli a kultúra széles körú terjesz tését és azt, hogy az emberiséget igazságosságra, szabadságra és békére neveljék, és e téren valamennyi nemzetre a kölcsönös segités és gondoskodás szellemében elvégzendô szent köteles ségek hárulnak. Az olyan béke, amely kizárólag a kormányok po litikai és gazdasági jellegű megállapodásain alapul, nem hozhat ja el a világ népeinek egyöntetű, tartós és őszinte összefogását, tehát a tartós alapokon nyugvó békét az emberiség szellemi és erkölcsi együttérzésére kell alapozni" (Blahó és Prandler, 2001, 151-153. o.).

Az UNESCO-t létrehozó államok a szervezet célját az alábbiak szerint határozták meg:

„a béke és biztonság fenntartását azáltal segíti elő, hogy a ne velés, a tudomány és a kultúra révén szorosabbra füzi a nem zetek közötti együttmúködést abból a célból, hogy faji, nemi, nyelvi vagy vallási megkülönböztetés nélkül mindenki számára világszerte biztosítsa az igazság, a törvény és ama emberi jogok és alapvető szabadságjogok tiszteletben tartását, amelyeket az Egyesült Nemzetek Szervezetének Alapokmánya az összes népek javára elismer" (Wolters Kluwer, 2009, I. cikk, 1. pont).

Az alapokmány világos alá- és fölérendeltségi viszonyt, prioritási sorrendet határoz meg az ENSZ elsődleges célkitűzése és az annak elérését szolgáló, az UNESCO kompetenciájába tartozó nevelésügyi, tudományos és kulturális vonatkozások, feladatok és kötelezettségek között. Az UNESCO az ENSZ szakosított intézményeként nem lebeg valamiféle politikamentes térben, hiszen mennyiben lehetne politikamentes az a szervezet, amely az alapokmánya szerint olyan értékek mellett kötelezi el magát, amelyek az emberiség egészének közös ér dekéhez, a béke és a biztonság fenntartásához, illetve az emberi és szabadságjogokhoz kötődnek. Ezeknek az értékeknek a bemutatása, meggyőző képviselete, védelme a politika lényegét jelenti. Másrészről viszont az ENSZ-család eddigi története azt mutatja, hogy a békéhez és biztonsághoz vezetô utat a különböző országok és csoportjaik 


\section{Külïgyi Szemle}

sokszor nagyon is eltérően képzelték el, annak akadályait, a békebon tókat, a biztonság megsértőit rendszeresen a velük szemben álló or szágokban és csoportjaikban látták. Az Alkotmány megfogalmazza az emberi jogok tiszteletben tartásának a kötelezettségét is, ami bizonyos szinten eredendően politikai problémákat okoz(ott) a szervezet mandátumának a végrehajtása során. A dolgozat kereteit jóval meghaladná annak részletes megvizsgálása, hogy az emberi jogokat, azok meglétét, lényegét, tartalmát, a tiszteletben tartásuk elsődlegességét mennyire eltérően értelmezik a különböző kultúrák és civilizációk.

Az átpolitizálódás tartalmának a meghatározásához fontosnak tartom az Amerikai Egyesült Államok kormánya és az UNESCO főigazgatója közötti 1984-es üzenetváltást. Az USA abban az eszten dőben - december 31-i hatállyal - kilépett a szervezetből, indoklásul az átpolitizálódás vádját fogalmazta meg vele szemben. George P. Shultz külïgyminiszter a kilépést bejelentő levelében ugyanakkor azt is hangsúlyozta, hogy országa és az amerikai nép változatlanul egyetért a szervezet alkotmányában lefektetett elvekkel. Ezzel együtt kiemelte: az Egyesüilt Államok a Végrehajtó Tanácsban és másutt tett nyilatkozataiban már évek óta egyértelművé tette, hogy aggódik az UNESCO politikájában, ideológiai hangsúlyaiban, költségvetésében és irányításában erőteljesen megjelenő azon tendenciák miatt, amelyek aláássák a szervezet hatékonyságát. Ezek a trendek az UNESCO-t az alapokmányában megfogalmazott eredeti elvektől eltávolították, és egyes tagállamok politikai céljait, nem pedig az UNESCO nemzetközi hivatásának a beteljesítését szolgálták. Az Egyesült Államok mindent megtett annak érdekében, hogy e trendek megfordítására ösztönözze a szervezetet, és az ismét az alapító államok által megfogalmazott célokra összpontosítson, szigorúan kerüilje el, hogy egyik vagy másik nemzeti politika szolgájává váljon. Múködése során jutalmazza a hatékonyságot, elősegítse a programjai félelem nélküli értékelését, és a prioritásokat a programjai értéke, nem pedig a múltbeli szokások, a politikai célszerűség vagy más idegen megfontolások alapján alakítsa ki (UNESCO Digital Library, 1984, 2. o.). 
Amadou Mahtar M'Bow, az UNESCO akkori fỏigazgatója a válaszában emlékeztetett arra a tényre, hogy a szervezetet államok hozták létre, és az irányító testületei államközi jellegủek. Ez pedig szerinte „rávilágit arra, hogy a tagállami küldöttségek közötti viták különbözỏ nézőpontokat és világnézetet tükröznek... A tagállamok képviselőiből álló testületekben a delegációk által kifejezett, alkalmanként ellentétes vélemények [megfogalmazása során] valóban arra törekszenek, hogy elfogadtassák azokat az álláspontokat, amelyek a legjobban szolgálják a nemzeti érdekekeit... Választóvonalat kell húzni az UNESCO valamely tagállama, illetve a tagállamai meghatározott csoportjai által kifejezett álláspontok és magának a szervezetnek a tevékenysége között. Ez utóbbi etikai szerepe azt diktálja, hogy haladja meg a partikuláris ideológiákat, anélkül, hogy ignorálná azokat" (UNESCO Digital Library, 1984. 5-6. о.).

A fóigazgató arra is hivatkozott, hogy a Közgyúlés által hozott határozatok döntő többségét 1976 óta konszenzussal fogadták el, más szavakkal: „a szervezet tevékenységét nem a tagállamok olyan többségi akarata határozta meg, amely negligálta volna a kisebbség véleményét, hanem az összes képviselt tagállam szándéka” (UNESCO Digital Library, 1984, 5-6. о.).

Az ENSZ-család valamely adott tagja minősüllhet szakosítottnak, de nem várható el, vagy nem követelhető meg tỏle, hogy apolitikus legyen. Sót, az akár a hibájául is felróható lenne, mert már a reálfolyamatok felismerését szolgáló képességek és szándékok hiányára utalna. Mindenképpen számolni kell tehát esetükben a természetes és elkerüllhetetlen politizálódással. Ezen intézményeknek - így az UNESCO-nak is - tiszteletben kell tartaniuk az alapokmányukban megfogalmazott célokat, eszközöket, módszereket. A politika, a politizálódás megjelenése a nemzetállamok, a nemzetállami érdekek léte és ütközése, a nemzetállamok és szövetségeik által képviselt világné zeti, ideológiai, illetve civilizációs különbségek azonban semmiképpen nem zárhatóak ki, és végső soron nem tekinthetők e szervezetek eredendô hibájának vagy szervezeti gyengeségének. 


\section{Külïgyi Szemle}

Samuel P. Huntington ismert véleménye szerint a „hidegháború utáni világ összetartásának, széthúzásának és konfliktusainak szabályait a kultúra és a kulturális - végső szinten civilizációs - identitások alakítják" (Huntington, 2018. 15. o.). Akár törvényszerúnek is értékelhetjüik e kulturális, civilizációs különbségeknek a megjelenését és a politikai színezetű és indíttatású összeüitközését az UNESCO-ban is. Ezért is használom az átpolitizálódás kifejezést, mert jobban kifejezi azt a helyzetet, amikor a politizálódás már konfrontációs szakaszba lép.

Az UNESCO alkotmányának a fentiekben idézett megfogalmazásából logikusan levonható az a következtetés is, hogy azzal ellentétes minden olyan nevelésüigyi, kulturális és tudományos tevékenység, folyamat, határozat, elköteleződés a szervezetben, amely nem szolgálja a tartós világbékét és biztonságot, a nemzetek közötti együttmúködést, az emberi jogok és alapvető szabadságjogok védelmét. Valószínúleg itt tárhatók fel az „átpolitizálódás” megalapozott vagy mondvacsinált kérdésének, jelenségének a gyökerei. Az adott történelmi helyzetekben, a felmerülő ügyek, kiéleződött viták, összetűzések értékelésekor éppen az a kulcskérdés, hogy a folyamatok a politizálódás „természetesnek" tekinthető szintjét átlépik-e, és már az átpolitizálódás szóval jellemezhetők-e vagy sem. Véleményem szerint, ahogyan magával az átpolitizálódás jelenségével kapcsolatban sincs soha egyetértés az érintett felek között, úgy a politizálódás „természetes” szintjének a megállapítására vonatkozó értékelés lehetősége kapcsán is negatív a válasz.

Az átpolitizálódás jelensége mögött sokszor az a jól megfogható törekvés áll, hogy a szakosított intézményekbe olyan ügyeket vigyenek be, amelyek egyszerűen nem oda tartoznak, hanem kívül esnek az adott szervezet alapokmányában meghatározott hatáskörön. Az ilyen törekvések képviselóinek az a célja - általánosító jelleggel is megfogalmazhatóan -, hogy a sérelmeiket minél szélesebb körben, minden lehetséges fórumon, bármilyen eszköz felhasználásával megismertes sék a világgal, minél inkább tudatosítsák azokat a nemzetközi nyilvánosságban, s így szerezzenek támogatást a saját álláspontjuknak. Ezzel azonban - szintén általánosítva - inkább csak bénítják az adott 
szakosított intézmény szakmai tevékenységét, véget nem érő, termé ketlen és ott meg sem oldható viták kiprovokálásával rontják annak nemzetközi megítélését, ráadásul még a saját ügyüket sem viszik elő re. Az UNESCO történelmében több példát is lehet erre felsorakoz tatni.

Az UNESCO-ban és intézményeiben tapasztalható átpolitizáló dás meghatározását a fentiek alapján igyekszem megfogalmazni. Az „át-” igekötő használata már eleve arra utal, hogy valamiből valami - részben vagy egészben - más lett, vagyis megváltozott. A kifeje zésből érzékelhetô rosszalló hangsúly pedig azt mutatja, hogy ez az emberi viszonyokat, tevékenységi terüileteket, értékeket érintő folyamat negatív természetű, nem kívánatos, ráadásul még ismétlődhet is. Az átpolitizálódás e dolgozatom tárgyának keretei között azt jelenti, hogy az UNESCO-t, illetve az érintett intézményeit a szakmaiságnak az alapokmányukban meghatározott keretei közül kiléptetik - elsősorban a döntéseket, határozatokat kezdeményező egyes tagállamok vagy azok csoportjai, a többségi akaratukat akár szavazás révén is ér vényesítve -, és szándékosan a politikai térbe terelik. Így azokat az alapokmányukkal ellentétes irányba mozgatják, vagy olyan ügyek tár gyalására kényszerítik, amelyek nem tartoznak a hatáskörüikbe.

Alkalmanként előfordult az is, hogy az UNESCO-t a vezetői - ter mészetesen elsősorban a főigazgatói - saját fellépése nyomán érte az átpolitizálódás vádja, másrészt viszont a tapasztalatok szerint ők éppen az e kifejezéssel jellemzett vagy annak minősített folyamatoknál a megoldást elősegítő közvetítő szerepében is megjelenhet nek. A véletlenszerúség vagy a szándékosság hiánya egyik esetben sem feltételezhető, az átpolitizálódás jelenségét tudatos tevékenység váltja ki, és ez - magától értetődően - a folyamat fontos jellemvonásaként határozható meg.

Az átpolitizálódás mindig viszonylagos jellegű, annak valamely fél által történő megállapítása, hangoztatása mindig elutasításra talál a másik, az abban érintett fél részérỏl. A jellegét tekintve valamiféle vádló és vádlott közötti viszonyra emlékeztet, azzal, hogy itt nem léteznek tör vénykönyvek, nincs bíróság, illetve az igazság megállapítására, a döntés 


\section{Külïgyi Szemle}

meghozatalára hivatott fórum. Még az sem bizonyítja szüikségszerúen valamelyik fél igazát, ha az a saját álláspontjához jelentős vagy akár döntő mértékú támogatást, adott esetben szavazati többséget szerez. A vádlók szerint az átpolitizálódás esetén a vádlott és támogatói „bűnössége" nem annyira (vagy egyáltalán nem) a saját cselekedeteikben nyilvánul meg, hanem abban, hogy az UNESCO-t és intézményeit „rossz utakra” viszik, mert a döntésekben, határozatokban azok hibás, alapokmány-ellenes vagy nem a szervezet kompetenciájába tartozó álláspontja jelenik meg.

\section{Történelmi előzmények}

\section{A hidegháború idószaka}

Az átpolitizálódást vizsgálva megállapítható, hogy történelmileg nem modern, 21. századi jelenségről van szó: az UNESCO esetében már a kétpólusú világrendszer, a tömbpolitizálás, illetve a hidegháborús feszültség erősödésének idején is megfigyelhető volt.

1952-ben például Magyarország már az UNESCO tagja volt, de az ENSZ-be történő felvételére 1955-ig kellett várnia. 1952. december 30-án Molnár Erik, a Magyar Népköztársaság külügyminisztere an gol nyelvű, durva hangú táviratban azzal vádolta meg az UNESCO-t, hogy az „az imperializmus ügynökévé vált”. Azt hangsúlyozta, hogy a szervezetet azért hozták létre, hogy előmozdítsa a béke nagy ügyét, és ezért határozott úgy a magyar kormány, hogy tevôleges szerepet vállal a tevékenységében. Most már azonban arra kényszerül, hogy megállapítsa: „az UNESCO nem váltja be a hozzá füzött reményeket”, nem teljesíti az Alapokmányban meghatározott feladatait; ellenkezőleg: „az amerikai háborús politika szervilis kiszolgálójává vált”. Ez a politika pedig fenyegetést jelent a kulturális fejlődésre, így az UNESCO a hidegháború eszközévé süllyedt. A magyar kormány folyamatosan felhívta a szervezet figyelmét erre a veszélyre - hangsúlyozta a küilügyminiszter, majd tételesen felsorolta mindazokat a fejleményeket, amelyek kormánya álláspontja szerint - bár magát a kifejezést nem 
használta - az átpolitizálódást mutatják: a koreai „amerikai agresz szió”3 támogatását; a bonni kormány melletti kiállást; annak megakadályozását, hogy a Kínai Népköztársaság elfoglalhassa Kína helyét a szervezetben; a Hitlerrel lepaktált „fasiszta Franco-rezsim” felvételét a szervezetbe. Mindez azt igazolta a magyar kormány szerint, hogy az UNESCO támogatja az imperialista politikát és a fasizmus újjászületését. Mindezek miatt a magyar kormány „a továbbiakban nem tekintheti magát a szervezet tagjának" (UNESCO Digital Library, 1953, 6. o.).

Ezt a fellépést az adott korszak „sajátosságaként”, a feltétlen szovjet szupremáciának a magyar külpolitikában való leképeződéseként kell értékelni. Kétségtelen azonban, hogy akkoriban az USA és az azt követő nyugati államok domináns szerepet játszottak az UNESCO ban, amelynek a Szovjetunió akkor még nem volt a tagja. Ezt a helyzetet az Egyesült Államok ki is használta a politikai céljai elérése ér dekében.

A két szuperhatalom befolyási övezetének az 1945 utáni kialaku lásakor „a régió többi országával együtt Magyarország is hosszú évtizedekre a szovjet érdekszféra és egyben a szovjet birodalom részévé vált. Ezért a hagyományos értelemben vett önálló nemzeti küilpolitikáról 1945 után Magyarország esetében nem beszélhetünk, hiszen az ország vezetésének mindenkori külpolitikai lépéseit kényszerủen a szovjet birodalomhoz való tartozás ténye határozta meg" (Békés, 2011, 95. o.). A szovjet blokk országai, így hazánk számára az 1948 1953 közötti időszak „az önkéntes bezárkózást, a nyugati kapcsolatok befagyasztását, a propagandában pedig a totális hidegháborús szembenállást jelentette" (Békés, 2011, 104. o.). Az UNESCO-ellenes magyar fellépés során hangoztatott vádaskodás a szovjet küilpolitikának az adott kérdésben képviselt álláspontját, illetve annak elsődleges, kiemelten fontos elemét, az amerikai imperializmus bírálatát visszhangozta. A szovjet-amerikai szembenállás kiéleződésében szerepet játszott az amerikai külpolitikának az a meggyőződése, hogy a helyzet

3 A koreai háború valós okairól, jellegéről és történetéről lásd Messenger, 1995. 318-323. o. 


\section{Külïgyi Szemle}

súlyosbodásának az oka nem az amerikai fél oldalán és hibáiban, ha nem a másik táborban keresendő. Washington „a Szovjetunióval folytatott vitákat magában a szovjet rendszerben rejló állandó vonásként kezelte" (Kissinger, 1996, 434. o.). A szovjethez hasonló ideológiai alapokon nyugvó magyar rendszer húséges követőnek bizonyult.

Akkoriban - a fiatal szervezet tagállamai számának a növekedésével párhuzamosan - a Molnár Erik levelében megjelent probléma többször is felmerült. Valamely kormányközi szervezetben egy tagállam képviselete akkor válik politikai kérdéssé, ha annak kormányát néhány más tagország nem ismeri el legitimnek, vagy ha két versengő kormány létezik, és mindkettő önmagát tekinti a törvényesnek. Ilyen körülmények között a szervezet döntését, függetlenül annak tartalmától, valamelyik fél részrehajlónak fogja tekinteni. Magyarország is ezzel a problematikával szembesült, amikor az 1956-os forradalmat követő két közgyủlési üilésszakon a Kádár-kormány delegáltjainak az akkreditálásával súlyos nehézségei támadtak.

\section{Az enyhülés idószakában}

Az elóbbi példa a fokozódó nemzetközi feszüiltségek, a nukleáris fegyverkezési verseny, a harmadik világháború elkerülhetetlensége miatti félelem fokozódása, illetve az arra való készülődés időszakából szár mazott. Nyilvánvalóan vajmi kevés köze volt az UNESCO szakmai te vékenységéhez és teljesítményéhez, sokkal inkább tükrözte a két világrendszer ideológiai harcát, illetve Budapestnek a Moszkvától függő helyzetét. Ezt mutatja az is, hogy végüil a Molnár Erik táviratában szereplő kitétel ellenére hazánk nem lépett ki UNESCO-ból, és az ügy hamvába holt. ${ }^{4}$ Sztálin 1953. márciusi halála után a Szovjetunió külpolitikáját - minden megtorpanás, a szakadék szélén való táncolás (így például a kubai rakétaválság) ellenére - fokozatosan, de végső soron kikényszerítetten - a két társadalmi rendszer békés egymás

4 1954. június 2-án megjelent a sajtóban, hogy a magyar külügyminiszter a kormány megbízásából levelet írt az UNESCO főigazgatójának, amelyben bejelentette, hogy Magyarország ismét részt vesz a szervezet munkájában (Békés és Kecskés D., 2006, 139. о.). 
mellett élésének az elmélete határozta meg. E fordulatot a magyar külpolitika az UNESCO-ügyben is figyelembe vette.

A gyarmati rendszer megszűnésének időszakában elsősorban az Egyesült Államok és szövetségesei részérôl hangzott el az UNESCOban - a Szovjetunióval és az általa befolyásolt, illetve uralt szocialista táborral szemben - az átpolitizálódás vádja. Azt állították, hogy azok a szervezet szakmai ügyeibe politikai tartalmat vegyítenek, a saját politikai céljaikat tükröző határozatokat igyekeznek a szervezettel elfogadtatni, illetve az UNESCO-t - sok kérdést szakosított ügynek álcázva vagy azok keretében - eszközként igyekeznek a politikai céljaik elérése érdekében felhasználni. Ez az időszak is világosan megmutatta, hogy az átpolitizálódás tényének, tartalmának, jellegének meghatározásában nem alakulhat ki egyetértés: az ellentétek - a politikai érdekeknek és irányvonalaknak megfelelően - döntően áthidalhatatlanoknak bizonyulnak. A vádló fél még a látszólag legnyilvánvalóbb esetekben sem számíthat arra, hogy megvádolt elismeri a vádak jogosságát.

Az eddig bemutatott két időszak azt igazolja, hogy az átpolitizáló dás jelensége mögött a két világrendszer közötti ideológiai harc állt. A vád mindkét esetben ideológiai indíttatású volt, és mögötte a szocialista rendszer terjesztésének, illetve a feltartóztatás politikájának az összeütközése rejlett.

\section{Korunk átpolitizálódási jelenségei,folyamatai}

A nevelésügy, a tudományos és a kulturális élet kérdései, irányítása sem nemzeti, sem nemzetközi szinten nem választható el a társadalmi, politikai környezettől. Erre a szoros kapcsolatra - a prioritási sor rend meghatározásával együtt - az alapokmány fent jelzett kitétele világosan utal. A rendszerváltozás, a kommunista-szocialista kísérlet világméretű kudarca óta az átpolitizálódás jegyében folytatott viták elsősorban már nem ideológiai, világnézeti, hanem hatalmi, geopolitikai, etnikai és civilizációs természetǔek. 


\section{Külïgyi Szemle}

Samuel P. Huntington idézett munkájában arra emlékeztetett, hogy az egyik, széles körben ismert paradigma szerint a „hidegháború végeztével a jelentős konfliktusok lehetősége is megszúnt a világpolitikában, és megszületett egy relatíve harmonikus világ." Arra is utalt, hogy e modell legrészletesebb megfogalmazását Francis Fukuyama adta „a történelem végéről” kialakított tézisében. "Nagyon sokan számítottak erre a harmóniára" - folytatta a fukuyamai idézet után a saját gondolatmenetét Huntington:

„A politikai és szellemi vezetők hasonló nézeteket fogalmaztak meg. A berlini fal leomlott, a kommunista rendszereknek befellegzett, az ENSZ, mondták, az addiginál jelentősebb szerepet fog betölteni, a korábbi hidegháborús ellenfelek »partnerként« fognak együttmúködni, és "egy nagy üzlet« szereplői lesznek, a fő napirendi pontok pedig a békefenntartás és béketeremtés lesznek... A hidegháború befejezésének pillanatában az euforikus hangulat a harmónia érzetét keltette, de hamarosan kiderült róla, hogy nem egyéb illúziónál... Az egyetlen harmonikus világ paradigmájáról bebizonyosodott, hogy végtelenül messze jár a valóságtól, s hasznavehetetlen a hidegháború utáni világ kalauzaként" (Huntington, 2018, 30-32. o.).

Ha ilyen a mostani világunk, akkor innen már egyenes úton juthatunk el ahhoz a következtetéshez is, hogy így az UNESCO-ban, ahol a különböző civilizációk államai képviseltetik magukat, nem szűnt, és nem is szúnhetett meg a konfliktusok lehetősége.

5 A múvében idézte Fukuyamát: „egyszerủen a történelem végének [vagyunk tanúi]: tehát az emberiség ideológiai fejlődése befejeződésének, annak, hogy végső kormányzati formaként sor kerül a nyugati liberális demokrácia általános bevezeté sére" (Huntington, 2018, 30 o). 


\section{Palesztina}

Az UNESCO-tagság elnyerése,

a Végrehajtó Tanács Paleszlinával kapcsolatos határozatai

A közel-keleti válság és következményei hosszú-hosszú évtizedek óta sújtják a közvetlenül érintetteket, és az ügy fontosságának megfelelő, legkomolyabb összpontosításra késztetik a világpolitikát és a regioná lis politikát alakító, illetve befolyásoló nemzetközi tényezőket, a szak értők sokadalmát, valamint a nemzetközi közvéleményt.

Dolgozatom tárgya szempontjából Palesztinának az UNESCO ban folytatott tevékenysége különös figyelmet érdemel. Ennek jegyében igyekszem azt a változási, végső soron evolúciós folyamatot fő vonalaiban áttekinteni, amely az UNESCO-ban és a Világörökségi Bizottságban az átpolitizálódás sokatmondó példájaként indult, és napjainkra valamiféle törékeny kompromisszumhoz vezetett. Sajnálatos tény viszont, hogy közben a jelenlegi legfontosabb világpolitikai tényezőnek, az Egyesüilt Államoknak, továbbá Izraelnek az UNESCO-ból való kilépésével járt, illetve annak egyértelműen a közvetlen kiváltó oka volt.

Az UNESCO Közgyűlés 2011. október 31-én vette fel - az ENSZ családban elsőként - a szervezet teljes jogú tagjának Palesztinát. A palesztinkérdés már a csatlakozást megelőzően is jelen volt, ${ }^{6}$ de azóta erőteljesen uralja az UNESCO fórumainak a napirendjét, pedig ez a szervezet nem az a nemzetközi politikai küzdőtér, ahol a közel-keleti válságot meg lehetne oldani.

Az Egyesült Államok és Izrael 2013 novemberében, az Alkot mány rendelkezéseinek megfelelően, elvesztette a szavazati jogát az UNESCO Közgyúlésében, mert megtagadta a tagdíjfizetést - álláspontjuk szerint a palesztin ügyekben tapasztalható átpolitizálódás miatt. Az USA az 1990-ben hozott, 22 USC 287e jogszabályra hivatkozott, amely szerint „sem az Egyesült Nemzetek Szervezete,

6 Palesztinának a szervezet munkájában való részvételét, valamint a lehetséges csatlakozását már 1993-ban és 1995-ben is tárgyalta az UNESCO Közgyúlése (UNESCO Digital Library, 1993; UNESCO Digital Library, 1995). 


\section{Külïgyi Szemle}

sem annak bármely szakosodott ügynöksége nem rendelkezhet olyan pénzeszközökkel, amelyeket e törvény vagy bármely más jogi aktus igénybe vehet, és amelyek a Palesztin Felszabadítási Szervezetnek a tagállamokkal azonos státuszt biztosítanak" (Govinfo, 1990).

Az UNESCO egyre súlyosbodó költségvetési hiánya ellenére az Egyesült Államok szilárdan ragaszkodott a lépéséhez: továbbra is tevékenyen részt vett ugyan a szervezet munkájában, de a közgyúlési szavazati joga felfüggesztése ellenére nem fizette a tagdíjat. Kihasz nálta viszont azt a jogi kiskaput, amely lehetôvé tette, hogy ha a legmagasabb döntéshozatali fórumban nem is, de az ottani döntéseket előkészítő Végrehajtó Tanácsban (VT) továbbra is szavazati joggal ve gyen részt a munkában, és ezáltal befolyásolhassa a Közgyưlés dönté seit is. ${ }^{7}$ Mindez azonban már előrevetítette annak a lehetőségét, hogy megfontolja az UNESCO ismételt elhagyását.

A Végrehajtó Tanács egymást követő ülésszakain „Megszállt Pa lesztina” címmel hoztak határozatokat, amelyekben a már évek óta napirenden tartott ügyekről, a megszállt arab területeken lévő oktatá si, kulturális és vallási intézmények helyzetéről, Jeruzsálemről, illet ve a gázai újjáépítésről volt szó (pl.: UNESCO Digital Library, 2015a; UNESCO Digital Library, 2015b). Újra és újra felhívták Izrael figyelmét arra, hogy tartsa be az előző határozatokat, különösképpen a hívőknek az al-Aksza-mecsethez történő zarándoklásának a biztosítását, amely a zsidó-keresztény kultúrkörben a Templom-hegy néven ismert jeruzsálemi helyszínen található. Palesztina elsődleges célja az volt, hogy teljes jogú tagként az UNESCO szakmai tevékenysége által meghatározott összes keretet és fórumot kihasználja, s Izraellel és az Egyesült Államokkal egyenrangú félként a saját politikai ügye, vala mint Izrael elítélése érdekében tevékenykedjen. Ezt a szándékát következetesen támogatták és támogatják az arab országok, de a fejlett országok között és a harmadik világban is számos segítőre számíthat.

7 Ezt a jogi kiskaput az UNESCO Közgyúlése a 40. ülésszakán, az Alapokmány 2019-es módosításával megszüntette, és a szavazati jog elvesztése azóta a VTtagságra is érvényes. 
A VT külkapcsolatokkal foglalkozó bizottságában 2016-ban lezajlott vita és szavazás utáni napon az izraeli oktatásügyi miniszter, aki egyúttal az UNESCO Izraeli Nemzeti Bizottságának a fótitkára volt, hivatalos levelet juttatott el Irina Bokova fóigazgató asszonyhoz. Ebben tudatta, hogy a határozatok elfogadása miatt az Izraeli Nemzeti Bizottság megszakítja a kapcsolatát az UNESCO-val, vagyis nem vesz részt a közös munkában, nem küld szakértőket a kormányközi bizottságokba (BBC, 2016; The Jerusalem Post, 2016).

Az UNESCO-hoz akkreditált izraeli nagykövet akkor még cáfolta és félreértelmezésnek minősítette a nemzetközi sajtóban megjelent híreket, amelyek szerint az ország teljesen megszakítja a kapcsolatát az UNESCO-val. A Benjamin Netanjahu miniszterelnökkel folytatott konzultációját követően kijelentette, hogy Izrael ismét elítélte, mégpedig teljes joggal, az elfogadott határozatokat, de a szavazások eredményét az izraeli diplomácia az előző ülésszakokhoz képest előrelépésnek tartja. Ezért nem várható, hogy hazája és az UNESCO kapcsolatának egészét - tehát a szervezetből történő kilépést - érintő bejelentés érkezzen a külügyminisztériumból is (Israel Ministry of Foreign A/fairs, 2016).

Az izraeli oktatásügyi miniszter, illetve az izraeli közvélemény éles reakciója bizonyos szempontból meglepó volt. A Végrehajtó Tanács, valamint a Világörökségi Bizottság akkor már évek óta rutinszerủen fogadott el palesztin és arab kezdeményezések nyomán Izraelt elítélő határozatokat. A VT 2016. őszi ülésszakán az említett szavazás eredménye az általános megítélés szerint kifejezetten kedvező volt. A rizikó Izrael szemszögéből ugyanis soha nem az volt, hogy a döntés megszületik-e vagy sem. Hiszen az 58 tagú VT összetételéból adódóan, valamint a történeti előzmények alapján a határozattervezetek szövegétől függetlenül azzal kellett számolnia, hogy létrejön az elítélỏ határozathoz szüikséges többség. A tét sokkal inkább az volt, hogy hány igen szavazattal fogadják el azt, és közülï̈k mennyi lesz az uniós voks. Az, hogy az UNESCO Izraeli Nemzeti Bizottsága mégis megszakítja az együttmúködést a szervezettel, jóval érthetőbb lett volna például 2016 áprilisában, amikor a 2016. ôszi 24-nél sokkal több, 33 


\section{Külïgyi Szemle}

igen szavazattal és kritikusabb tartalommal ment át az elítélő határo zat, és még semmilyen utalás sem szerepelt benne Jeruzsálemnek az iszlám mellett a másik két egyistenhívő vallásban betöltött különlege sen fontos szerepére (UNESCO Digilal Library, 2016).

Az adott körülmények között jelentős figyelem övezte a VT-ben történteket a nemzetközi sajtó részéről. Több olyan államban - köztük Magyarországon (IVG, 2016; Euronews, 2016) -, ahol a helyi média korábban kevés figyelmet fordított a 2010 ősze óta rendszeresen napirenden lévő, hasonló tematikájú VT-döntésekre, ezúttal a nyomtatott és az elektronikus sajtó, továbbá a televízió is beszámolt a fej leményekről.

A szervezet főigazgatójától eredő, korábban csak elméleti szinten lehetségesként említett átpolitizálódás jelenségére Irina Bokova főigazgató asszony adott példát: a szavazást követő napon a szervezet honlapján nyilatkozatot jelentetett meg, „Jeruzsálem óvárosáról, a világörökségi helyszínről” címmel. Ebben Jeruzsálemnek a három nagy monoteista vallásban betöltött különleges szerepére emlékezte tett, ugyanakkor egy szóval sem említette a Végrehajtó Tanács küilkapcsolatokkal foglalkozó bizottságának az előző napi döntését. Mint írta, ő már a Világörökségi Bizottság 2016. évi ülésszakán is hasonló jellegű nyilatkozatot tett. A főigazgató mindkét esetben kerülte a politikai tartalmú jelzőket és megfogalmazásokat, de világosan utalt arra, hogy a muszlimok al-Aksza-mecsete a zsidók számára szent helyen, a Templom-hegyen található, ahol a vallásuk szerint a kétszer lerombolt szentély állt. Bokova hangsúlyozta: mindannyiunk közös érdeke és felelőssége a vallási és kulturális egyuittélés elősegítése (UNESCO, 2016).

Válaszul Rijád al-Malki palesztin külïgyminiszter néhány órán belül éles hangvételű hivatalos nyilatkozatot tett (Palestine News and Info Agency, 2016). Szerinte Irina Bokova túllépte a hatáskörét, amikor a VT által elfogadott döntés ellen érvelt, és jobban tenné, ha Jeruzsálem ügyében az UNESCO kulturális örökségvédelmi mandátumának és a tagállamok döntésének a végrehajtásán dolgozna. Erőteljesen kifogásolta azt is, hogy a főigazgató nyilatkozata figyelmen kívül hagyja a vonatkozó határozatban a három monoteista vallás és Jeruzsálem 
kapcsolatára tett utalást. A külüigyminiszter jelezte: Palesztina továbbra is minden rendelkezésre álló jogi és diplomáciai úton védelmezi a palesztin nép jogait, ideértve az ENSZ intézményeit is. Hazáját nem akadályozzák meg a torzulások és a lejárató kampányok, és továbbra is nyomást fog gyakorolni a nemzetközi közösségre, hogy vállaljon felelősséget a palesztin helyzet iránt, és lépjen fel az izraeli jogsérté sek ügyében. Malki nyilatkozata visszakanyarodást jelentett a korábbi, durván Izrael-ellenes palesztin határozattervezetek szövegéhez.

A nyilatkozatváltással kapcsolatban kijelenthető, hogy bár a fő igazgató asszony nem utalt a VT döntésére, de a fellépése időzité séből mégis arra lehetett következtetni, hogy arra kívánt reagálni. Ez nem az első alkalom volt, amikor ebben az ügyben megszólalt: először 2015 őszén, az akkori szavazást megelőző napon foglalt ál lást a jeruzsálemi határozattervezet kapcsán (UNESCO, 2015). Ab ban nyíltan arra ösztönözte a VT tagjait, hogy ne fogadjanak el olyan döntést, amely további erőszakhullámhoz vezethet a Közel-Keleten. A palesztin küldöttség akkor csak informális keretek között reagált, de hivatalosan nem válaszolt a főigazgató nyilatkozatára. A tényszerú elemzés érdekében megállapítandó, hogy 2016 őszén a palesztin külügyminiszter joggal kifogásolta, hogy Bokova figyelmen kíviul hagyta a külkapcsolatokkal foglalkozó bizottság által elfogadott határozat azon mondatát, amely Jeruzsálem és a három nagy monoteista vallás különlegesen fontos kapcsolatára utalt. Tulajdonképpen érthetetlen volt a főigazgató nyilatkozatának ez a szembetűnő ténybeli hiányossága.

A kérdés az volt, hogy milyen üzenetet hordoz a palesztin küldöttség számára a kialakult helyzet. A 2016. őszi VT-határozat az áprilisinál sokkal „puhább” szöveg volt: A palesztinok a velük szemben évek óta támasztott követelést - azt, hogy legyen benne utalás Jeruzsálem többvallású jelentőségére (mivel korábban nem voltak hajlandóak az al-Aksza-mecset megemlítésekor annak zsidó-keresztény nevét, a Templom-hegyet is megjeleníteni) - ugyanis első ízben voltak haj landóak teljesíteni. Ennek ellenére a határozat sokkal kevesebb igen szavazatot kapott, mint korábban, és nagyobb, nem feltétlenüil Palesz tinának kedvező nemzetközi vitát okozott. 


\section{Külïgyi Szemle}

A VT 2017. őszi ülésszakán, október 12-én, az Egyesült Államok váratlanul bejelentette, hogy - a szervezet fennállása óta immár má sodik alkalommal - 2018. december 31-i hatállyal kilép az UNESCO ból. A hivatalos indoklás szerint a döntés oka az UNESCO-ban eluralkodott Izrael-ellenes elfogultság, de az általa sürgetett, a szerve zetben szükséges reformok elmaradását is kifogásolta.

$\mathrm{A} z$ amerikai bejelentés tartalmilag nem nélkülözte az előzménye ket, hiszen a tagdíffizetés szüneteltetését is hasonlóan indokolta. Az időzítése azonban meglepő volt. Hosszú idő óta ugyanis ekkor történt meg először, hogy a „menetrendszerủen” napirendre kerülő, Izraelt elítélő határozatot vita nélkül elhalasztották, vagyis az Egyesült Államoknak és Izraelnek a 2016. évi VT-ülésszakokat követő eróteljes diplomáciai fellépése és tiltakozása eredményt hozott. Másrészt az USA a Közgyủlésben - mint arról már szó volt - a tagdịjfizetés megtagadása miatt nem szavazhatott ugyan, a VT-ben viszont rendkívüli aktivitást fejtett ki, és meg két évig a testület tagja lett volna. ${ }^{8}$

A kilépéssel az Egyesült Államoknak a szervezeten belül a köz vetlen befolyásolási potenciálja korlátozódott, és a történelmi példák messzemenően igazolják az ilyen típusú lépések haszontalanságát, sőt bumerángjellegét. Ez a visszavonulás, a terep másoknak való átengedése - akárcsak egy részterületen is - elméleti szinten kevéssé volt összeegyeztethető az „America First” jelszóval és az abból eredő logikus külpolitikai következtetésekkel.

A bejelentésnek egyrészról tehát az adott pillanatban nem volt konkrét, az Izrael-ellenes elfogultságra vonatkozó indoka, másrészrôl a Közgyủlés 2017. évi ülésszaka elé jelentős reformesomag került, amelynek a kidolgozásában az Egyesült Államok tevékenyen részt vett. Ez utóbbinak voltak ugyan olyan elemei, amelyek a nemzetközi politikai színtér „nagyjainál”, így Washingtonnál is egyöntetủ ellenállást váltottak ki, de a kilépés bejelentése előtt semmi sem utalt arra, hogy azoknak ilyen súlyos következményük lenne, és az amerikai döntés

8 Bár az Obama-adminisztráció a tagdíffizetés visszaállítására vonatkozó javaslatot tett, a tények azt mutatják, a Kongresszus elutasította a kezdeményezést (United States Department of State, 2013. 52. o., lábjegyzet). 
elsődleges okaként nem is lehetett azokat megnevezni. ${ }^{9}$ Washington sem tette ezt.

Mindezek alapján az a vélemény is megfogalmazódhatott, hogy a bejelentésnek taktikai indoka volt, amely szorosan összefüggött a VT főigazgató-jelöltjeiről épp akkoriban folyt szavazással. Ez volt az utolsó pillanat az USA számára, hogy a távozási szándéka bejelenté sével nyomást gyakoroljon a VT tagjaira, és megakadályozza, hogy a szervezetnek arab fóigazgatója legyen. Az addigi szavazási fordulók ugyanis a katari jelölt vezetésével zárultak, de még nem született végleges döntés arról, hogy ki lesz az a két személy, aki bekerüil az utolsó fordulóba (az eredeti kilenc induló közül az egyiptomi, a francia és a katari jelölt maradt még versenyben), és azt követően a VT melyik jelölt nevét terjeszti a Közgyűlés elé. Amennyiben a kilépést az arab jelölt megválasztása után jelentette volna be az Egyesüllt Államok, akkor az egyértelműen arabellenes indíttatásúnak tűnt volna, így viszont időt adott a VT tagjainak (illetve a Közgyűlésnek), hogy mérlegelés és újabb megfontolás tárgyává tegyék a döntésüket.

Ennek fényében több mint meglepő volt, hogy a bejelentést követően Katar jelöltje tovább erősödött, és biztos eredménnyel került be a végső szavazási körbe. Az egyiptomi jelölt voksainak száma is gyarapodott, míg a franciáé nem változott. Ez arra utalt, hogy amennyiben valóban a szavazás eróteljes befolyásolása volt az amerikai szándék, az ebben a körben még nem járt eredménnyel. Ugyanakkor tény, hogy végüil - bár csupán egyetlen szavazatnyi többséggel - a francia jelöltet választották meg az UNESCO úij foóigazgatójának.

A kilépés 2018. december 31-i hatállyal történő bejelentése az Egyesuilt Államok számára is lehetőséget adott a döntés felülvizsgálatára. A legkisebb mértékben sem vitatható, hogy az UNESCO elsődleges érdeke az aktívan politizáló, a tagdíját rendesen fizető Egyesült Államok jelenléte, a szervezet azonban 195, egyenrangú tagot számlál.

9 Elsődleges példaként azt említem, hogy a reformcsomag kísérletet tett a VT tagság időtartamának szabályozására, vagyis megpróbált fellépni a kvázi „örökös”. azaz hogy a nemzetközi politika legfontosabb tényezőinek a megszakítás nélküli VT-tagságának a gyakorlata ellen. 


\section{Külïgyi Szemle}

Végső soron a döntés az amerikai külpolitika türelmetlenségét jelen tette, de annak a kifejezését is, hogy megunta az érdekei és a véle ménye sorozatos figyelmen kívül hagyását - akkor még csak - az UNESCO-ban. Félő volt azonban, hogy a döntése precedens értékủ lehet, és általánosabb irányváltást is jelezhet, és akkor további súlyos következményekkel is számolni kell. Az ilyen amerikai intézkedések közé sorolhatjuk az Emberi Jogi Tanácsból történő kilépést, de azt is, hogy az USA tényleg végrehajtotta az UNESCO elhagyását.

Azóta a VT-ben gyakorlat, hogy az arab országok egy-egy csoportja újra és újira benyújtja az Izraelt elítélő határozattervezeteit, de - már „szokásos” módon - a döntés elhalasztását és a VT követke zô ülésének a napirendjére tűzését kéri. Erre eredetileg minden bizonnyal azért volt szükség, mert a szervezet vezetéséért 2017 őszén három arab jelölt is versenyben volt, és el akarták kerülni, hogy az Izrael-ellenesség vádja miatt szavazatoktól essenek el, hiszen a határozattervezeteknek az őket delegáló országok - Egyiptom, Libanon és Katar - is társszerzỏi voltak, és épp azon az ülésszakon fogadták volna el, amikor a fỏigazgató megválasztása történt.

Ennek megfelelően a két „bevett” napirendi pontról („Oktatási és kulturális intézmények helyzete a megszállt arab területeken", illetve „Megszállt Palesztina”) szóló döntést vita nélkül hozzák meg az érintett testületek, és azt követően nincsenek szavazatmagyarázó felszólalások sem. Hasonló megoldás született a Világörökségi Bizottság napirendjén szereplő „Jeruzsálem óvárosa” nevű világörökségi helyszín határozattervezetei kapcsán is.

\section{Paleszlina és a Vilägörökségi Bizollság}

Az átpolitizálódás „klasszikus” példájával találkozhattunk a Világörökségi Bizottság (VöB) 41. ülésszakán, 2017 júliusában, Krakkóban. A Hebron világörökségi helyszínné nyilvánításáról szóló döntés kifeje zetten tanulságos módon példázza az átpolitizálódás jellemzőit, esz közeit, ezért szintén érdemes hosszabban bemutatni annak körülmé nyeit és fejleményeit (UNESCO, 2017a, 217-225. o.). 
Palesztina 2017 januárjában nyújtotta be a saját várományosi listá ján 2012 óta szereplő „Hebron/al-Khalil óváros” helyszín nevezését a Világörökségi listára. Az eljárási rend szerint a jelöléseket a bizottság a benyújtást követő évi ülésszakán vizsgálja, ezért a Hebronnal kapcsolatos vizsgálat 2018-ban lett volna esedékes. Márciusban azonban Palesztina sürgősségi eljárást kért, és kezdeményezte az óvárosnak a Veszélyeztetett világörökségi helyszínek listájára történó azonnali felvételét is. A Világörökségi egyezmény eljárási szabályzatának 161. és 162. bekezdésére hivatkozott, amelyek alapján a jelölést ilyen esetben már a benyújtás évében napirendre kell tủzni. A kérést többek között azzal indokolta, hogy egyrészt az Izrael Állam katonai felügyelete alatt álló Hebronban az óváros folyamatosan veszélynek van kitéve, másrészt Izrael több mint tíz éve nem hajlandó az UNESCO Végre hajtó Tanácsa által hozott vonatkozó határozatok teljesítésére.

Az ICOMOS-nak, a Világörökségi Központ (VöK) tanácsadó tes tuiletének az értékelése viszont nem tartalmazott egyértelmủ állás foglalást és javaslatot a VöB határozatára vonatkozóan. Az izraeli hatóságok ugyanis megtagadták a misszió helyszíni szemléjéhez való hozzájárulást. Az ICOMOS ezért azt jelentette, hogy a helyszíni vizs gálat híján nem tudja minden kétséget kizáróan megállapítani, hogy egyrészt a javasolt helyszín rendelkezik-e a listára való felvételhez szükséges, kiemelkedő egyetemes értékkel, másrészt valóban olyan veszélyek fenyegetik-e, amelyek alapján jogosult a sürgősségi eljárás. A további lépések érdekében a tanácsadó testuilet a helyszíni misz szió mielőbbi kiküldését, illetve annak izraeli engedélyezését kérte (UNESCO, 2017b).

A VöB ülésén már a napirendi pont elővezetésekor heves vita ala kult ki. Libanon ugyanis ügyrendi javaslat keretében kifogásolta, hogy a titkárság az ülést megelőző napokban három bekezdéssel megtoldotta a dokumentumot, amelyben összefoglalta a tízoldalas szakvé leményt. Ezt azonban csak a VöB tagjainak küldték meg. A libanoni küldött felháborítónak nevezte, hogy a titkárság „manipulálja” a bizottságot, és minden jóváhagyás nélküil hozzányúlt a tanácsadó tes tület által készített dokumentumhoz. Az UNESCO kultúráért felelős 


\section{Külïgyi Szemle}

főigazgató-helyettese a vádaskodást visszautasította, és hangsúlyozta: egyszerủen a bizottság tagjainak a munkáját akarták megkönnyíteni. Libanon viszont veszélyes precedensnek nevezte az eljárást, és köve telte, hogy a titkárság vonja vissza az összefoglaló kiegészítést. Miu tán Kuba, Tunézia, Kuvait, Zimbabwe is támogatta, hogy a módosított dokumentumot vessék el, és térjenek vissza az eredetihez, az ülés elnöke ennek megfelelő döntést hozott (UNESCO, 2017a, 213. o.).

A napirendi ponttal kapcsolatos egyeztetés elején az elnöklő Lengyelország kezdeményezte, hogy a Libanon, Kuvait és Tunézia által benyújtott módosításokról - amelyek alapján a VöB azonnal felvenné a hebroni óvárost a veszélyeztetett világörökségi helyszínek listájára titkos szavazással döntsenek. Ezt Jamaica és Horvátország támogatta, Kuvait nyílt szavazást kért, amit Kuba, Libanon és Tunézia támogatott. Mivel az UNESCO jogi tanácsadója szerint a titkos szavazás elsőbbséget élvez, az elnök elrendelte annak megkezdését (UNESCO, 2017a, 220. o.).

A libanoni képviselő a szavazás előtti felszólalásában azt hangsúlyozta, hogy a szakértőik véleménye szerint a helyszín rendelkezik kiemelkedő egyetemes értékkel, a város szimbolikus jelentőséggel bír mindhárom nagy monoteista vallás számára, és a zarándokhely köré épített egyedi városi szerkezetben azok hívei egymás mellett élnek. Mindezek alapján egyértelmúen indokolt a listára való felvétele.

Izrael nagykövete, Karmel Sama-Hakohen hangos szóváltásba ke veredett az ülésszak elnökével és a palesztin nagykövettel, és a vita hevében terroristának nevezte a libanoni küldöttség egyik tagját. A konfliktus azért robbant ki, mert Sama-Hakohen a véleménykifejtés szabadsága és intimitása biztosítása érdekében szavazófüllkék felállítását kérte a titkos szavazás lebonyolításához. Ez azonban - mivel az UNESCO és intézményei gyakorlatában általában nem szokás szavazófülkét felállítani - nem történt meg, és a nagykövet szerint így viszont a kamerák kereszttüzében a VöB több tagja is ódzkodott az elutasító voks leadásától (YNet, 2017). A szavazás eredményeként a 21 tagú bizottság 12 igen, 3 nem és 6 tartózkodással megszavazta a határozatot (UNESCO, 2017a, 222. o.), így Hebron/al-Khalil óvárosa felkerült a Veszélyeztetett világörökségi listára. 
A szavazást követően Izrael nagykövete beszédében „,ïdvözölte” Hebronnak az ülésszakon részt vevő polgármesterét, aki - mint arra Sama-Hakohen emlékeztetett - az 1980-as években izraelieket gyilkolt, amiért huszonöt évig ült börtönben. Ezt követően a kubai szakértőnek felrótta, hogy amikor egyperces néma felállással történô tiszteletadást kért az összes palesztin áldozatért, akkor közéjüik sorolta a terroristákat és a Hamász tagjait is. Az izraeli nagykövet továbbá elfogadhatatlannak tartotta a holokauszt és a palesztin nép sorsa közötti párhuzamot. A német nagykövettől számon kérte, hogyan tehetett eleget a kubai kérésnek, és hogy a véleménye a német kormány álláspontját tükrözi-e a holokauszttal kapcsolatban. Sama-Hakohen beszéde közben többször is csörgött a telefonja, amikor pedig végüil felvette, közölte a jelenlévőkkel: a vízvezeték-szerelő hívta, mert a rezidenciáján gond van a mosdóval, és az számára sokkal fontosabb, mint a bizottság döntése. Ezt követően az izraeli küldöttség kivonult a teremből (Ahren, 2017).

A palesztin nagykövet kijelentette: azt az „arrogáns” közjátékot, aminek a jelenlévők a tanúi lehettek, a testvérei nap mint nap átélik, és egyúttal megköszönte a VöB döntését.

A megfigyelők közüil Kanada, az Egyesült Államok és Ausztrália képviselője szólalt fel. Ők elítélték a döntést, és bírálták, hogy a VöB a tanácsadó testület véleménye ellenére vette fel a helyszínt azonnal a Veszélyeztetett világörökségi listára. Az Egyesült Államok küildötte hangsúlyozta: amennyiben hagytak volna időt, hogy a jelölés a rendes ciklusban kerüljön a VöB elé, az akár a békés együttmúködés példája is lehetett volna. ${ }^{10}$

A szavazás Izrael szempontjából kifejezetten rosszul végződött. Eredetileg ugyanis jó esélyei voltak arra, hogy a titkos szavazás révén a VöB - tiszteletben tartva a tanácsadó testületnek a fenntartásokkal teli véleményét - a Hebron óvárosára vonatkozó jelölést elutasítja, és további vizsgálódásról dönt az ügyben. A hazájában politikusként

10 Az ügy a nemzetközi sajtó érdeklődését is kiváltotta. Az MTI október 7-én részletes összefoglalót adott ki a VöB döntésének izraeli fogadtatásáról és elutasításáról amit több sajtó orgánum is átvett (pl. 168.hu, 2017; 444.hu, 2017) 


\section{Külïgyi Szemle}

jegyzett izraeli nagykövet magatartása azonban már nem az első al kalommal vált általános bírálat tárgyává, s gyengítette az izraeli ér dekek védelmének a hatékonyságát. A titkos szavazás lebonyolításával kapcsolatos felháborodásának azonban tényleg volt formális alapja. Ilyen esetekre alakult ki az a gyakorlat, hogy a szavazatot leadó de legációvezető elhagyja az üléstermet, hogy azon kívïl töltse ki a sza vazólapot, így biztosítva a szüikséges titkosságot, majd visszatér az ülésterembe, ahol leadja a voksát. Ezzel együtt a szavazás titkos jelle ge a technikai kellékek hiánya miatt kérdésessé vált. Pedig egyes nem hivatalos információk szerint az izraeli küldöttség már hónapokkal az ülés előtt megkereste a lengyel elnököt, és arra kérte, hogy amenynyiben titkos szavazásra kerül sor, álljanak rendelkezésre az ahhoz szüikséges szavazófüilkék. Erre ígéretet is kaptak, de mivel nem teljesítették, ez lett a közvetlen oka a nagykövet magatartásának (Jerusalem Post, 2017). Joggal feltételezhető, hogy lengyel részről előzetesen ala posan mérlegelték az izraeli kérést, és nem az ülés elnökének az ad hoc, egyéni döntése vagy technikai-szervezési hiányosságok miatt nem biztosították a szavazófüllkéket.

A politikai vetületen túl a VöB döntésének a szakmai vonatkozá sai is súlyosak. Az ugyanis a korábbiaknál is veszélyesebb tendencia kezdetét jelentette, mivel nemcsak a tanácsadó testüilet álláspontját, hanem az egyezmény múködési irányelveinek is a teljes figyelmen kívuil hagyásával fogadták el. A határozattervezetbe például - bár az ICOMOS úgy foglalt állást, hogy nem találja bizonyítottnak a helyszín kiemelkedő egyetemes értékét - Libanon, Tunézia és Kuvait olyan be kezdést szúrt be, miszerint a VöB véleménye az, hogy a hebroni óvá ros minden kétséget kizáróan rendelkezik vele. A Világörökségi egyez mény múködési irányelveinek 154-155. bekezdése (UNESCO, 2019a, 92. o.) világosan kimondja, hogy valamely helyszínnek a Világörökségi listára való felvételéhez a VöB-nek egy kiemelkedő egyetemes értékre vonatkozó nyilatkozatot (Statement of outstanding universal value, SOUV) kell elfogadnia, amelyben felsorolja, hogy a lehetséges tíz kritériumból melyek alapján érdemel a helyszín világörökségi státuszt. Hiába szúrta tehát be a kiemelkedő egyetemes érték meglétéről szóló 
bekezdést a libanoni küldött a VöB állásfoglalásába, ha SOUV nem született. Hebron ezért egyértelműen szabályellenesen került fel a listára."

E precedenstől kezdve kérdésessé válhat a tanácsadó testületek léte és munkája, szakmai hitelessége. Az ügy tanúsága szerint ugyanis elfogadottá válhat, hogy a szakértői véleményeket negligálva, politikai erőfölényt tükröző szavazataránnyal születnek szakmainak álcázott, illetve annak minősített döntések. A bizottságnak jogában áll elfogadni vagy átírni a tanácsadó testüilet véleményét, amelyet eddig alapvető, minden mást megelőző szabályként vett figyelembe. A jelenlegi rendszert éppen azért alakították ki, hogy biztosítsák a döntések szakmai megalapozottságát. A Hebronéhoz hasonló, újabb éles polémia még nem alakult ki, de azzal kell számolni, hogy a Világörökségi Bizottságnak át kell gondolnia a jövőt, illetve a lehetséges következményeket, főként annak fényében, hogy Palesztina ún. várományosi listáján 13 helyszín szerepel, amelyek közül több potenciális konfliktus forrását jelentheti Izrael szempontjából. ${ }^{12}$ Ráadásul, ha bármely jelölés sikert arathat amennyiben kellő politikai nyomás és megfelelő számú szavazat van mögötte, a Világörökségi lista hitelessége is megkérdőjeleződhet, és egy-egy világörökségi helyszín jelölési és felvételi folyamata színjátékká korcsosulhat, veszélyeztetve az UNESCO egyik, a nemzetközi közvélemény által is ismert és elismert eredményét.

További kérdéseket vet fel a Hebronról szóló SOUV. A vita nélkül elfogadott 2019-es döntés melléklete (UNESCO, 2019b) szerint a Tanácsadó Testületnek és Palesztinának azt még ki kell dolgoznia. A palesztinok által az ülésszakra benyújtott állapotmegőrzési jelentés (State of Palestine, 2019) az elvárt és megszokott szakmai helyett erősen politikai töltetű szöveget tartalmaz. Izraelre következetesen „megszálló erőként” utal, és azon kívüil, hogy a várost „a különböző vallások és kultúrák találkozóhelyeként” vagy a „három monoteista

11 A cikk készítésének időpontjában, 2021 áprilisában Hebron még mindig nem rendelkezett SOUV-vel.

12 Például a vitatott tulajdonú holt-tengeri tekercsek lelőhelye, Kumrán városa is szerepel a Palesztina által a Világörökségi listára javasolt helyszínek között (UNESCO, é. n..). 


\section{Külïgyi Szemle}

vallás fontos városaként" írja le, azt semmilyen explicit utalásban nem minősíti a zsidó és keresztény vallás számára jelentős zarándokhelynek, hanem a római kortól keletkezteti a történetét. A helyszín kiemelkedô és egyetemes jellegének bizonyításaként nem említi annak bibliai, ótestamentumbeli jelentőségét (pl. Dávid király fơvárosa volt hét éven keresztuil). Jelzi ugyan, hogy zarándokhely volt, de azt nem, hogy a zsidók számára, viszont hosszasan tárgyalja a helyszínnek az iszlám követői (szúfizmus) lelki életében betöltött jelentőségét.

A kérdés politikailag egyértelműen érzékeny, és nem csak a két érintett fél - Palesztina és Izrael - számára, hiszen a vallások közötti konfliktusok tükröződnek a jelentésben, a kereszténység és a zsidóság közel-keleti eredetének a „mellőzésével”. Az eddigi tapasztalatok alapján a kérdés várhatóan hosszú időn keresztül fogja uralni a Világörökségi Bizottság napirendjét.

\section{Koszovó}

Koszovó a függetlensége 2008. évi kikiáltását követően folyamatos erőfeszítéseket tett a nemzetközi színtéren való elismertségének a kétoldalú alapokon történő erősítésére, majd az e folyamatban elért eredmények után, 2015-ben megkísérelte az UNESCO-tagság elnyerését. Az Alkotmány 1. cikkelye szerint „az Egyesült Nemzetek Szervezetében viselt tagság feljogosít az Egyesült Nemzetek Nevelésügyi, Tudományos és Kulturális Szervezetében való tagságra” (Wolters Kluwer, 2009). Koszovó azonban nem tagja az ENSZ-nek; erre a függetlensége elismerését kitartóan megtagadó Szerbia, illetve a Biztonsági Tanácsban vétójoggal rendelkező Oroszország és Kína ellenállása miatt gyakorlatilag nines is reménye. Az Alkotmány 2. cikkelye szerint azonban „ezen Szervezet és az Egyesült Nemzetek Szervezete között létrejött, a jelen Alkotmány X. cikke szerint jóváhagyott megállapodás rendelkezéseire figyelemmel, az Egyesült Nemzetek Szervezetében tagsággal nem rendelkező államokat, a Végrehajtó Tanács ajánlásával, az Általános Konferencia kétharmados többségi szavazattal felveheti a Szervezet tagjainak sorába” (Wolters Kluwer, 2009). Az UNESCO 
Végrehajtó Tanácsában és a Közgyủlésben nincsen vétójog, így attól a lehetőségtől Koszovónak nem kellett visszarettennie, hogy bármely ország ellenszavazata elegendő lenne a csatlakozási kísérlete meghiúsításához. Ez adott először elméleti szinten, majd a gyakorlatban is lehetőséget arra, hogy Pristina elindítsa a felvételi kérelmét, ami azonban végső soron - a Közgyűlés 2015-ös ülésszakán három szavazat híján - sikertelennek bizonyult (erről részletesen lásd: Erdős Zeichner, 2017). Valószínűsíthető, hogy a tagállamok a szavazatuk leadásakor szem elôtt tartották Henry Kissinger, a volt amerikai küilügyminiszter és kiemelkedő tudományos tekintély értékelését, miszerint „a történelem tanulmányozása nem biztosít automatikusan alkalmazható használati utasítást. A történelem analógiákon keresztül tanít, oly módon, hogy összehasonlítható helyzetek esetén bemutatja a lehetséges következményeket. Ámde minden generációnak magának kell eldöntenie, hogy melyek az összehasonlítható szituációk” (Kissinger, 1996, 19. o.). Úgy tűnik, sok tagállam összehasonlíthatónak értékelte Koszovó ügyét és a Palesztina felvétele után kialakult helyzetet, és nem akart újabb, nyilvánvalóan alapvetően politikai természetú és egyelőre megoldhatatlannak tűnő vitát a szervezet napirendjére be emelni.

A szerb-koszovói politikai konfliktus az UNESCO kompetenciáját érintő kérdésben már a csatlakozási kezdeményezést megelőzően jelentkezett, amikor Szerbia kezdeményezte „Koszovó középkori műemlékei” helyszínnek a Világörökségi listára való felvételét. Ez a tétel négy szerb ortodox templomot, illetve kolostort foglalt magában, amelyek jelenleg is a szerb pravoszláv egyház tulajdonában és gondozásában vannak, és a kérés idején felkerültek a veszélyeztetett helyszínek listájára is. Az UNESCO, illetve a Világörökségi Bizottság Koszovó füiggetlenségének kikiáltása után sem változtatott a korábbi döntés tartalmán, megnevezésén, státusán, ezzel akarva-akaratlanul, de áttételesen arra utalt, hogy nem vitatja a Koszovó feletti szerb szuverenitást.

A világörökségi helyszínek védelme visszatérő elem volt a feleknek a koszovói tagság melletti, illetve ellene szóló UNESCO-specifikus 


\section{Külïgyi Szemle}

érvelésénél. Szerb részről azt hangoztatták, hogy „1999 óta a koszovói albánok kétszáz ortodox templomot gyújtottak fel, valamint nyolcvanezernél is több sírkövet tettek tönkre." A szerb külügyminiszter - nem takarékoskodva a megalapozatlan minősítésekkel sem - Koszovót az Iszlám Allamhoz hasonlította, és azt hangsúlyozta, hogy olyan állam nem csatlakozhat a legfőbb kulturális és örökségvédelmi szerve zethez, amely célzott pusztítást vitt véghez a kulturális emlékekben (Erdős-Zeichner, 2017, 91-92. o.). A koszovói fél viszont folyamatosan azzal érvelt, hogy a csatlakozási kérelem benyújtásával már jelezte: teljes mértékben vállalja azokat a kötelezettségeket, amelyek a tagsággal járnak, és annak elnyerése után mindenben tiszteletben tartja a világörökségi emlékeket.

Meg kell azonban jegyezni azt is, hogy az UNESCO-specifikus elemek csak az egyik, és egyáltalán nem a legfontosabb tényezôt je lentették a Végrehajtó Tanács, illetve a Közgyűlés üléseit megelőző, majd az ülésszakokon is folytatódó koszovói-szerb csatározásokban, sôt háttérbe szorultak a nemzetközi jogi és politikai szempontok mögött. Mindkét oldal döntően politikai kérdésként kezelte Koszovónak az ENSZ szakosított szervezetébe való felvételét, s ezzel a szervezetben jelentkező átpolitizálódás egyik „kiváló” példáját mutatták.

A felek a saját nemzeti érdeküik szempontjából igyekeztek irányítani az ügyet. A nemzeti érdek fogalmát a mindennapi nyelv, de még a hagyományos külpolitikai analízis naiv nyelve is bizonyos célokkal azonosítja, és a külpolitika feladatát abban látja, hogy adott körüilmé nyek között egy ország céljainak a minél teljesebb megvalósulását biz tosítsa (Romsics, 2009, 187. o.). Az ilyen típusú nemzetiérdek-felfogás ra példaként említhető Szerbiának a Koszovó függetlenségéhez való viszonya, és ez élesen megjelent Pristina UNESCO-felvételi kérelmével kapcsolatban is. Nem férhet hozzá kétség, hogy a Koszovóban található szerb kulturális, vallási örökségi helyszínek védelme része a szerb nemzeti érdekeknek, és azokat jól szolgálhatta volna, ha Ko szovó teljesítményét, illetve annak az e területen mutatkozó hiányos ságait Szerbia az UNESCO-ban, illetve a Világörökségi Bizottságban is számon kérhette volna. Ehhez azonban be kellett volna engedni 
Koszovót az UNESCO-ba. Mivel azonban ezt szerb részről a koszovói függetlenség teljes körű nemzetközi elismeréséhez vezető út fontos állomásának tartották, és az alapvetőnek tekintett szerb nemzeti ér dekkel - a területi sérthetetlenséggel - szögesen ellentétesnek ér tékelték, azt minden rendelkezésre álló külpolitikai, diplomáciai esz közzel akadályozták. Ezzel pedig inkább veszni hagyták az UNESCO által a tágabb értelemben kezelt nemzeti érdekeik védelmében felkínált lehetőséget.

Koszovói részrôl viszont a függetlenség elismertetése jelent meg elsődleges, mindent háttérbe szorító nemzeti célként, és ezt szolgálták az UNESCO-tagság megszerzésére irányuló erófeszítések is. Az adott nemzetközi helyzetben inkább vállalták volna az UNESCO-ban várható erős szerb és nemzetközi bírálatokat a kulturális, oktatási, örökségvédelmi tevékenységüik gyengeségei, elégtelenségei miatt, csak lehessenek a szervezet tagjai, és ezáltal a nemzetközi jogi státusuk erősödjön.

\section{Konklúzió}

A cikk elején abból indultam ki, hogy az UNESCO nem tekinthető politikán kívüli szervezetnek, így nem is várható el, hogy távol tartsa magát a politikától, s ez nem is lehet vele szemben követelmény. Az átpolitizálódás ugyanakkor döntően negatív jelenségként értékelhető; maga a szó a kulturális, oktatási és tudományos területre áttevődő, arra rátelepüilő, sőt azt háttérbe szorító, politikai indíttatású, a konfliktusos helyzetek értékelésekor használatos terminológia. Az átpolitizálódás olyan különleges jelenség, vagy még inkább folyamat, amely az egyik fél szerint létezik, a másik szerint nem. Ez alapján egy-egy ügy az egyik érintett szerint megmaradt az UNESCO kompetenciá jában, a másik szerint viszont kilépett abból. Közös álláspont kialakulása nem várható, inkább újabb ügyek megjelenése valószínúsíthető a szervezet különböző szakosított bizottságainak a napirendjén. Ennek a legfrissebb példáját figyelhettük meg a 2020 őszén kirobbant azeriörmény harcok kapcsán is, hiszen mindkét fél szinte követelte, hogy 


\section{Külïgyi Szemle}

az UNESCO a másik felet hivatalosan elítélő nyilatkozatot adjon ki attól az oktatási, nevelésügyi vonatkozásokon túl politikai támogatást is remélve (Public Radio of Armenia, 2020; AzerNews, 2020).

Mindaddig, amíg eltérő nemzeti érdekek, azokat megjelenítő po litikai célok léteznek, illetve azokhoz jelentős nemzetközi támoga tás, szavazati többség biztosítható, illetve amíg léteznek kulturális, civilizációs különbségek, addig az „átpolitizálódás” jelenségével az UNESCO-ban és alárendelt intézményeiben is számolni kell. Mivel azokban minden ország szavazata egyenlő, és egyetlen állam sem rendelkezik vétójoggal, nem látható olyan hatékony szervezeti, jogtechnikai eszköz, amellyel eredendően meg lehetne akadályozni a szakmai tevékenység hatékonyságát csökkentő, az eredményességet adott esetekben gátló átpolitizálódás ismételt megjelenését - sem az eddig ismert, sem a jövőben minden bizonnyal napirendre kerüilő ügyekben.

\section{I rodalomjegyzék}

168.hu (2017). Izraelnek nem tetszik, hogy az UNESCO Hebront védett övezetnek nyilvánította. A letöltés ideje 2020. december 3. https://168. hu/kulfold/izraelnek-nem-tetszik-hogy-az-unesco-hebront-vedettovezetnek-nvilvanitotta-5308.

444.hu (2017). Izrael kiakadt, amiért az UNESCO palesztin világörökségi helyszínné nyilvánította Hebront. A letöltés ideje 2020. december 3. https:/444.hu/2017/07/07/izrael-kiakadt-amiert-az-unesco-palesztinvilagoroksegi-helvszinne-nvilvanitotta-hebront.

Ahren, Raphael (2017). Israel Reacts with Disgust and Disdain to UNESCO Hebron Decision. The Times of Israel. A letöltés ideje 2020. decem-

ber 3. https://www.timesofisrael.com/israeli-reacts-with-disgust-anddisdain-to-unesco-hebron-decision/.

AzerNews (2020). Azerbaijan Calls to Condemn Armenian Vandalism.

A letöltés ideje 2020. december 3. https://menafn.com/1101017950/ Azerbaijan-calls-to-condemn-Armenian-vandalism.

$B B C$ (2016). Israel Freezes Unesco Ties for 'Denying Jewish Holy Sites'. A letöltés ideje 2020. december 3. https://www.bbc.com/news/worldmiddle-east-37653910. 
Békés Csaba (2011). Magyar külpolitika a bipoláris világban, 1945-1991. Külügyi Szemle, 1O(4), 95-127.

Békés Csaba és Kecskés D. Gusztáv (2006). A forradalom és a magyar kérdés az ENSZ-ben, 1956-1963. Magyar ENSZ Társaság.

Blahó András és Prandler Árpád (2001). Nemzelközi szervezelek és intézmények. Budapest: Aula Kiadó.

Dutt, Sagarika (1995). The Politicization of the United Nations Specialized Agencies: Case Study of UNESCO. Lewiston, NY: Edwin Mellen Press.

Erdős-Zeichner Anna (2017). Koszovó kísérlete az UNESCO-tagság elnyerésére, nemzetközi elismertségének erősítésére. Külügyi Szemle, $16(2), 88-101$.

Euronews (2016). UNESCO: A zsidó népnek nincs köze Jeruzsálemhez. A letöltés ideje 2020. december 3. https://hu.euronews.com/2016/10/14/ unesco-a-zsido-nepnek-nincs-koze-jeruzsalemhez.

Govinfo (1990). Public Law 101-246. A letöltés ideje: 2020. december 3. https://www.govinfo.gov/content/pkg/STATUTE-104/pdf/STATUTE104-Pgl5.pdf.

Huntington, Samuel P. (2018). A civilizációs összecsapása és a világrend átalakulása. Budapest: Európa Könyvkiadó.

IIVG (2016). UNESCO: A zsidóknak semmi köze Jeruzsálemhez. A letöltés ideje 2020. december 3. https:/hvg.hu/vilag/20161013 Az ENSZ szerint a zsidoknak semmi koze Jeruzsalemhez.

Israel Ministry of Foreign Affairs (2016). PM Netanyahu Meets With Israel's Ambassador to UNESCO. A letöltés ideje 2020. december 3. https:// mfa.gov.il/MFA/PressRoom/2016/Pages/PM-Netanvahu-meets-withIsraels-ambassador-to-UNESCO-8-November-2016.aspx.

Jerusalem Post (2017). How Israel Lost the Hebron Vote. A letöltés ideje 2020. december 3. https:/www.jpost.com/International/How-Israellost-the-Hebron-vote-499644.

Kissinger, Henry (1996). Diplomácia. Budapest: Panem-McGraw-HillGrafo.

Messenger, Charles (1995). A háború évszázada. Világmérelü konfliklusok 1900-lól napjainkig. Pécs: Alexandra Könyvkiadó.

Palestine News and Info Agency (2016). Foreign Minister Malki Says UNESCO Director's Position Unacceptable. A letöltés ideje 2020. december 3. http://english.wafa.ps/page.aspx?id=OOvJMOa50649439401aOOvJMO. 


\section{Külïgyi Szemle}

Public Radio of Armenia (2020). UNESCO Urged to Condemn Azerbaijan's Continuous Targeting of Cultural Heritage Site. A letöltés ideje 2020. december 3. https:/en.armradio.am/2020/10/10/unesco-urged-tocondemn-azerbaijans-continuous-targeting-of-cultural-heritage-site/.

Romsics Gergely (2009). A leheletlen müvészele. Budapest: Osiris Kiadó.

State of Palestine (2019). State of Conservation Report for Hebron/Al Khalil Old Town - Palestine (Ref. 1565). UNESCO. A letöltés ideje 2020. december 3. https://whc.unesco.org/document/171887.

The Jerusalem Post (2016). Bennett Suspends Israeli Cooperation with UNESCO After Temple Mount Vote. A letöltés ideje 2020. december 3. https://www.jpost.com/Israel-News/Politics-And-Diplomacv/Bennettsuspends-Israeli-cooperation-with-UNESCO-after-Temple-Mountvote-470128.

UNESCO (2015). Statement by the Director-General of UNESCO, Irina Bokova. A letöltés ideje 2020. december 3. http://en.unesco.org/news/ statement-director-general-unesco-irina-bokova.

UNESCO (2016). Statement by the Director-General of UNESCO on the Old City of Jerusalem and Its Walls, a UNESCO World Heritage Site. A letöltés ideje 2020. december 3. https://whc.unesco.org/en/news/1568. UNESCO (2017a). United Nations Educational, Scientific and Cultural Organization. Convention Concerning the Protection of the World Cultural and Natural Heritage. A letöltés ideje 2020. december 3. http:// whc.unesco.org/archive $/ 2017 / \mathrm{WHCl}-41 \mathrm{COM}-\mathrm{inf} 18-S R s . p d f$.

UNESCO (2017b). Advisory Body Evaluation (ICOMOS). A letöltés ideje: 2020. december 3. https://whc.unesco.org/document/159759.

UNESCO (2019a). Operational Guidelines for the Implementation of the World Heritage Convention. A letöltés ideje: 2020. december 3. https:// whc.unesco.org/document/178167.

UNESCO (2019b). Hebron/Al-Khalil Old Town (Palestine) (C 1565). A letöltés ideje 2020. december 3. https://whc.unesco.org/en/decisions/7522.

UNESCO (é. n.). Palestine. A letöltés ideje: 2020. december 3. https://whc. unesco.org/en/statesparties/ps.

UNESCO Digilal Library (1953). 33 EX/20. Communications Recieved from the Governments of Hungary and Czechoslovakia. A letöltés ideje: 2020. december 3. https://unesdoc.unesco.org/ark:/48223/pfO000162650 eng?posInSet $=42 \&$ quervId $=\mathrm{N}-$ EXPLORE $-6042869 \mathrm{c}-6 \mathrm{~d} 55-4138-$ 9777-8ee69bd646c4. 
UNESCO Digilal Library (1984). 119/EX 14. Communication from the Secretary of State of the United States of America Concerning the Withdrawal of the United States of America. A letöltés ideje: 2020. december 3. https:/unesdoc.unesco.org/ark:/48223/pf0000059131?po sInSet=2\&quervld =a4b8efbf-724b-4f11-a6a9-7bae769cfd5e.

UNESCO Digilal Library (1993). 27 C/130. Request for the Admission of Palestine to UNESCO. A letöltés ideje: 2020. december 3. https:// unesdoc.unesco.org/ark:/48223/pf0000095461?posInSet=4\&quervId 7bc77982-0bd8-48a2-8086-cbf5d479de47.

UNESCO Digilal Library (1995). 28 C/128. Request for the Admission of Palestine to UNESCO. A letöltés ideje: 2020. december 3. https:// unesdoc.unesco.org/ark:/48223/pfO000101904?posInSet=6\&queryId= af46caab-b761-4e7a-8a44-d03c79932c7f.

UNESCO Digilal Library (2015a). 196 EX/26. Occupied Palastine. A letöltés ideje 2020. december 3. https://unesdoc.unesco.org/ark:/48223/pf 0000232326?posInSet $=4 \& q u e r v I d=c d f 7 f 5 c b-50 d 3-4419-b 3 a 2-$ ed9f20df8c71.

UNESCO Digilal Library (2015b). 196 EX/39. Draft Report of the Programme and External Relations Commission. A letöltés ideje 2020. december 3. https://unesdoc.unesco.org/ark:/48223/pfO000232764?posInSet=3\&qu ervld=b91leaa7-709b-4d13-a6c4-2aab9417dfle.

UNESCO Digilal Library (2016). 199 EX/19. Occupied Palestine. A letöltés ideje 2020. december 3. https:/unesdoc.unesco.org/ark:/48223/ pfOOO0244078.

Uniled States DeparlmentofState (2013). Executive Budget Summary. Function 150 \& Other International Programs. A letöltés ideje 2020. december 3. https:/www.usaid.gov/sites/default/files/documents/1868/183755.pdf. Wolters Kluwer (2009). 2009. évi XXXII. törvény az Egyesüllt Nemzetek Nevelésügyi, Tudományos és Kulturális Szervezete Alkotmányának kihirdetéséról. A letöltés ideje 2020. december 3. https://mkogv.jogtar. hu/jogszabaly?docid=a0900032.TV.

YNel (2017). Arab Envoy Apologizes for Not Voting Against UNESCO Resolution. A letöltés ideje: 2020. december 3. https://www.vnetnews. com/articles/0.7340.L-4986580.00.html. 